\title{
Aromatic acids in an Arctic ice core from Svalbard: a proxy record of biomass burning
}

\author{
Mackenzie M. Grieman ${ }^{1}$, Murat Aydin ${ }^{1}$, Elisabeth Isaksson ${ }^{2}$, Margit Schwikowski ${ }^{3}$, and Eric S. Saltzman ${ }^{1}$ \\ ${ }^{1}$ Department of Earth System Science, University of California, Irvine, Irvine, California 92697-3100, USA \\ ${ }^{2}$ Norwegian Polar Institute Fram Centre 9296, Troms $\varnothing$, Norway \\ ${ }^{3}$ Paul Scherrer Institute, Villigen, Switzerland and Oeschger Centre for Climate Change Research, University of Bern, \\ Bern, Switzerland
}

Correspondence: Mackenzie M. Grieman (mgrieman@uci.edu)

Received: 27 September 2017 - Discussion started: 4 October 2017

Revised: 15 March 2018 - Accepted: 17 April 2018 - Published: 23 May 2018

\begin{abstract}
This study presents vanillic acid and parahydroxybenzoic acid levels in an Arctic ice core from Lomonosovfonna, Svalbard covering the past 800 years. These aromatic acids are likely derived from lignin combustion in wildfires and long-range aerosol transport. Vanillic and para-hydroxybenzoic acid are present throughout the ice core, confirming that these compounds are preserved on millennial timescales. Vanillic and para-hydroxybenzoic acid concentrations in the Lomonosovfonna ice core ranged from below the limits of detection to 0.2 and $0.07 \mathrm{ppb}$, respectively $\left(1 \mathrm{ppb}=1000 \mathrm{ng} \mathrm{L}^{-1}\right)$. Vanillic acid levels are high (maximum of $0.1 \mathrm{ppb}$ ) from 1200 to $1400 \mathrm{CE}$, then gradually decline into the twentieth century. The largest peak in the vanillic acid in the record occurs from 2000 to $2008 \mathrm{CE}$. In the para-hydrobenzoic acid record, there are three centennialscale peaks around 1300, 1550, and $1650 \mathrm{CE}$ superimposed on a long-term decline in the baseline levels throughout the record. Ten-day air mass back trajectories for a decade of fire seasons (March-November, 2006-2015) indicate that Siberia and Europe are the principle modern source regions for wildfire emissions reaching the Lomonosovfonna site. The Lomonosovfonna data are similar to those from the Eurasian Arctic Akademii Nauk ice core during the early part of the record (1220-1400 CE), but the two ice cores diverge markedly after $1400 \mathrm{CE}$. This coincides with a shift in North Atlantic climate marked by a change of the North Atlantic Oscillation from a positive to a more negative state.
\end{abstract}

\section{Introduction}

Biomass burning influences the biosphere, atmospheric chemistry, and the climate system on both regional and global scales. Fire influences ecosystem dynamics, ecohydrology, surface albedo, and emissions of chemically and radiatively active aerosols and gases (Crutzen and Andreae, 1990; Legrand et al., 2016; Hessl, 2011; Bowman et al., 2009; Randerson et al., 2006). In boreal regions, fire plays a stabilizing role in circumboreal successional dynamics, influencing forest age structure, species composition, and floristic diversity (Soja et al., 2007). Boreal forest burned area, fire frequency, fire season length, and fire severity will likely increase with continued warming (Soja et al., 2007; Chapin et al., 2000). Arctic tundra fires are of particular concern because of their potential to release large amounts of ancient permafrost carbon into the atmosphere (Mack et al., 2011).

Understanding the role of fire in the climate system requires a knowledge of past regional and temporal variations on decadal, centennial, and millennial timescales. A number of proxy fire records have been developed from sediment cores and ice cores but systematic reconstruction of fire history remains a major challenge. Terrestrial sedimentary charcoal records are inherently local in extent, but regional and even global trends in burning have been developed from these records using various normalizing and averaging methods (Marlon et al., 2008, 2016; Power et al., 2008, 2013). The global charcoal database (GCD: Blarquez et al., 2014) is spatially and temporally inhomogeneous across the Northern Hemisphere boreal and Arctic regions, with good coverage in regions of North America and western Europe, and poor 
coverage in Asia. Dissolved and particulate constituents in ice cores have also been used as burning proxies. These include cations (ammonium, potassium), anions (formate, acetate, nitrate), and black carbon (see Legrand et al., 2016; Rubino et al., 2016, for recent reviews). One of the challenges of interpreting these records is that most of the dissolved ions have multiple sources, in addition to burning. For example, ammonium is also derived from biogenic marine and terrestrial sources, agriculture, and livestock (Legrand et al., 1992, 2016; Fuhrer et al., 1996; Savarino and Legrand, 1998; Bouwman et al., 1997; Rubino et al., 2016). Efforts to isolate the fire-derived contributions to these records have employed principle component analysis and peak counting methods. Eichler et al. (2009) examined a Siberian Altai ice core using a multiproxy approach, and concluded that potassium, nitrate, and charcoal were fire-related while ammonium and formate were biogenic in origin. The detailed interpretation of ice core chemical proxies is complicated by the fact that black carbon is emitted primarily during the flaming conditions, while ammonium and many organic aerosolborne constituents are emitted primarily during smoldering. Ice core gas measurements of methane and carbon monoxide, and their isotopomers, have also been used to derive histories of pyrogenic emissions (Ferretti et al., 2005; Wang et al., 2010). These gases have sufficiently long atmospheric lifetimes in that they integrate emissions over hemisphere/global scales.

A variety of organic aerosols are emitted from the burning of vegetation under smoldering conditions. Levoglucosan, a combustion product of cellulose, is considered a universal biomass burning tracer because it is emitted in greater quantities than most other burning-derived organic aerosols and is uniquely produced by the burning of plant matter (Simoneit et al., 1999). Levoglucosan has been detected in ice cores from Antarctica, Greenland, and northeast Asia (Gambaro et al., 2008; Kawamura et al., 2012; Zennaro et al., 2014). It is considered a qualitative tracer because it degrades rapidly in the atmosphere (Hoffmann et al., 2010; Hennigan et al., 2010; Legrand et al., 2016; Slade and Knopf, 2013).

Aromatic acids are among a wide range of phenolic compounds generated by lignin pyrolysis. These compounds are ubiquitous constituents of biomass burning aerosols and have been detected in polar ice cores. Lignin is produced from three precursor alcohols ( $p$-coumaryl alcohol, coniferyl alcohol, and sinapyl alcohol), and the resulting phenolic compounds retain the structure of these alcohols. The aromatic acids analyzed in this study are vanillic acid (VA) and $p$ hydroxybenzoic acid ( $p$-HBA). VA is predominantly associated with conifer and deciduous boreal forest tree species, while tundra grasses and peat generate primarily $p$-HBA with lesser amounts of VA (Simoneit, 2002; Oros and Simoneit, 2001a, b; Oros et al., 2006; Iinuma et al., 2007). pHBA is also produced from boreal conifer tree species (Oros and Simoneit, 2001a).
Burning is the only known source of these aromatic acids in aerosols or ice cores. Quantitatively, the ice core levels of these compounds result from the combined effects of emissions, atmospheric transport, depositional, and perhaps post-depositional processes. Aromatic acids can undergo re-volatilization at the snow surface. Laboratory experiments have shown that Arctic snow samples containing lignin-derived compounds photochemically react to produce formaldehyde and acetaldehyde (Grannas et al., 2004). Melting and refreezing processes have the potential to redistribute aromatic acids to lower depths. Meltwater at the surface percolates to deeper snow layers and water-soluble compounds are concentrated when the meltwater is refrozen (Wendl et al., 2015).

Prior studies of pyrogenic aromatic acids in ice cores include shallow cores from Greenland, northeast Asia (Kamchatkan Peninsula), and Europe (the Swiss Alps) (McConnell et al., 2007; Kawamura et al., 2012; Müller-Tautges et al., 2016). The record from Greenland showed that the timing of variability in the VA and black carbon records was similar over the past 200 years until around 1890 CE (McConnell et al., 2007). VA and $p$-HBA were elevated from the 1950s to the 1970s in the 60-year ice core record from the Swiss Alps (Müller-Tautges et al., 2016). VA and $p$-HBA were elevated in the 1700s and in the twentieth century in the ice core from northeast Asia over the past 300 years. There is only one millennial timescale ice core record of VA and $p$ HBA: a 2600-year Akademii Nauk ice core record from the Eurasian Arctic (Grieman et al., 2017). This record showed three major multi-century pulses of burning-derived aromatic acids, including one during the Little Ice Age (LIA; 1450$1700 \mathrm{CE})$.

Here we present measurements of vanillic acid (VA) and $p$-hydroxybenzoic acid ( $p$-HBA) in an Arctic ice core from the Lomonosovfonna ice cap in central Spitsbergen, Svalbard, which is located northeast of Greenland, in the Atlantic sector of the Arctic Ocean (Fig. 1). The goal of this study was to generate a record sensitive to conditions in northern Europe/northern Eurasia. Air mass back trajectories are used to examine the distribution and ecology of likely source regions for biomass burning aerosols transported to Svalbard. We discuss the variability observed in the ice core records of these compounds over the past 750 years, and compare the records to other proxy records of Northern Hemisphere climate and biomass burning.

\section{Methods}

\subsection{Ice core site characteristics and dating}

The Lomonosovfonna ice core site is $1202 \mathrm{~m}$ above sea level (a.s.l.) $\left(78.82^{\circ} \mathrm{N}, 17.43^{\circ} \mathrm{E}\right)$ (Fig. 1). The ice core was drilled in 2009 to a depth of $149.5 \mathrm{~m}$ by a team from the Paul Scherrer Institute and the Norwegian Polar Institute. The core did not reach bedrock and contains a continuous 


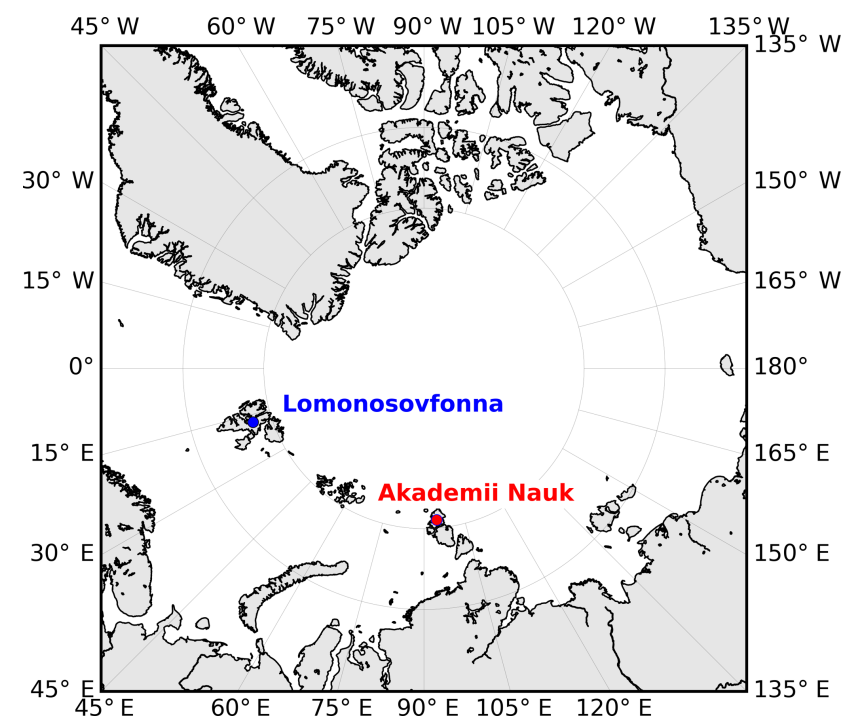

Figure 1. Location of Lomonosovfonna ice core drilling site on the island of Spitsbergen in Svalbard ( $\left.78^{\circ} 49^{\prime} 24.4^{\prime \prime} \mathrm{N}, 17^{\circ} 25^{\prime} 59.2^{\prime \prime} \mathrm{E}\right)$ and the Akademii Nauk ice core drilling site on Severnaya Zemlya $\left(80^{\circ} 31^{\prime} \mathrm{N}, 94^{\circ} 49^{\prime} \mathrm{E}\right)$. The map was produced in the Python "matplotlib" graphics environment (Hunter, 2007).

750-year record (Wendl et al., 2015). The near-surface annual average temperature of Lomonosovfonna is $-12.5^{\circ} \mathrm{C}$ at $1020 \mathrm{~m}$ a.s.l. (Beaudon et al., 2013; Pohjola et al., 2002; Zagorodnow, 1988). The annual average accumulation rate is $0.58 \pm 0.13 \mathrm{~m}$ w.e. year $^{-1}$ (Wendl et al., 2015). The firn/ice transition occurs at $13 \mathrm{~m}$ depth, at approximately $1997 \mathrm{CE}$.

The Lomonosovfonna ice core was dated by Wendl et al. (2015), yielding a time span for the core of 1222-2009 CE (Fig. S1 in the Supplement). Annual layers were counted using seasonal $\delta^{18} \mathrm{O}$ and $\mathrm{Na}^{+}$variations to a depth of $97.7 \mathrm{~m}$ (79.7 mw.e.), giving an age of $1750 \mathrm{CE}$ at that depth. The chronology of the upper section of the core was also constrained by the ${ }^{210} \mathrm{~Pb}$ profile and the $1963{ }^{3} \mathrm{H}$ horizon. The age scale below $97.7 \mathrm{~m}$ was developed using a simple glacier ice flow model (Thompson et al., 1998), assuming an average accumulation rate of $0.58 \pm 0.13 \mathrm{~m}$ w.e. year ${ }^{-1}$ (Wendl et al., 2015). The age scale was adjusted to match seven volcanic reference horizons. The oldest of these is the Samalas volcanic eruption of $1257 / 8$. Dating uncertainty was estimated by comparing purely modeled reference horizon years to known volcanic eruption years. Above $68 \mathrm{~m}$ w.e., the dating uncertainty is \pm 1 year within 10 years of reference horizons, and \pm 3 years otherwise. Between 68 and $80 \mathrm{~m}$ w.e., the dating uncertainty is \pm 3 years, and below $80 \mathrm{~m}$ w.e., the dating uncertainty is \pm 10 years (Wendl et al., 2015).

The Lomonosovfonna site experiences summer surface melting and winter refreezing (Wendl et al., 2015). Wendl et al. (2015) examined the distribution of melt layers in the Lomonosovfonna ice core, concluding that most summer melt layers are refrozen within the year, with some extending over 2 or 3 years. The frequency of melt layers increases after 1800 CE (Fig. S2; Wendl et al., 2015). During the warmest years of the twentieth century, percolation length reached 8 years. Due to possible redistribution of soluble compounds by melt, percolation, and refreezing, interannual variability of the aromatic acid signals is not interpreted in this study. Ten-year bin averages are used to illustrate short-term variability in the data (see Sect. 3.1).

\subsection{Potential source regions and ecological types using air mass back trajectories}

Air mass back trajectories were used to identify potential source regions and eco-floristic zones from which biomass burning aerosols are likely to reach the Lomonosovfonna ice core site. This analysis assumes modern-day meteorological conditions. Ten-day air mass back trajectories were computed using the HYSPLIT model with NCEP/NCAR reanalysis data (Draxler et al., 1999; Stein et al., 2015; Kalnay et al., 1996). The 10-day back trajectories were started at $100 \mathrm{~m}$ above the ice surface at 00:00 and 12:00 LT (local time) for three separate 10-year periods, 1948-1957, 1970-1979, and 2006-2015 CE. The fraction of trajectories originating in or transecting various geographic regions and eco-floristic zones was calculated for spring (1 March-31 May), summer (1 June-31 August), and fall (1 September-30 November). The geographic regions included in the study were North America, Siberia $\left(>42^{\circ} \mathrm{E}\right)$, and Europe $\left(<42^{\circ} \mathrm{E}\right)$. The boundaries of North America, Siberia, and Europe were defined using global selfconsistent, hierarchical, high-resolution geography database GIS shapefiles (Wessel and Smith, 1996). These regions were subdivided into eco-floristic zones defined by the Food and Agriculture Organization (FAO; Fig. S3; Ruesch and Gibbs, 2008, http://cdiac.ornl.gov/epubs/ndp/global_carbon/ carbon_documentation.html, last access: 1 February 2017).

The Siberian region has the highest fraction of trajectories to the Lomonosovfonna site, accounting for 39,15 , and $38 \%$ of the trajectories in spring, summer, and fall from 2006 to $2015 \mathrm{CE}$, respectively. Siberian trajectories were most commonly from boreal tundra woodlands, boreal conifer forests, and boreal mountain systems (Fig. S4; Table S1 in the Supplement). Fewer than 3\% of the trajectories transected other Siberian eco-floristic zones. Europe contributed fewer than $11 \%$ of the trajectories arriving at the site in any season. Those trajectories most commonly encountered boreal coniferous forests, boreal mountain systems, and temperate oceanic forests (Fig. S5; Table S1). Pollen species in the Lomonosovfonna ice core covering the past 150 years drilled in 1997 match northern boreal taxa from Fennoscandia (Hicks and Isaksson, 2006). Biomass burning aerosols from eastern European agricultural fires in 2006 reached Svalbard within a few days (Stohl et al., 2007). Other European eco-floristic zones contributed to fewer than $5 \%$ of the trajectories in any season. North America contributed 
fewer than $4 \%$ of the trajectories for any season. This analysis does not rule out contributions from North America, but it does suggest that such input would likely require considerably longer atmospheric transport times.

\subsection{Ice core sample preparation and analysis}

For this study, we resampled discrete ice core samples previously analyzed for major ions (Wendl et al., 2015). The original ice core samples were $1.8 \times 1.9 \mathrm{~cm}$ in cross section and $3-4 \mathrm{~cm}$ long, melted and stored frozen in polypropylene vials. For analysis of VA and $p$-HBA, the ice was re-melted, $1 \mathrm{~mL}$ was withdrawn from each vial, and the samples from four adjacent vials were combined into one. This resulted in a total of 993 samples. As discussed below, this sampling procedure resulted in decreasing temporal resolution with increasing depth from sub-annual samples at the surface to about 2-year samples at the bottom of the core.

VA and $p$-HBA in the ice core samples were measured using anion exchange chromatographic separation and tandem mass spectrometric detection in negative ion mode with an electrospray ionization source (IC-ESI-MS/MS). The analytical methods and standards used in this study are described in detail by Grieman et al. (2017). The experimental system consisted of a Dionex AS-AP autosampler, ICS-2100 integrated reagent-free ion chromatograph, and ThermoFinnigan TSQ Quantum triple quadrupole mass spectrometer. VA was detected at two mass transitions $(\mathrm{m} / z, 167 \rightarrow 108$ and $m / z 167 \rightarrow 152)$ and $p$-HBA was detected at $m / z 137 \rightarrow 93$.

Limits of detection for single measurements were estimated using three times the standard deviation of the Milli-Q water blank. The limits of detection for the VA $m / z 167 \rightarrow 108$ and $167 \rightarrow 152$ transitions were 0.010 and $0.006 \mathrm{ppb}(n=80)$, respectively. The limit of detection for $p$-HBA was $0.012 \mathrm{ppb}(n=80)$. The mass spectrometer signals for VA at the two mass transitions were highly correlated and either mass transition can be used to measure ice core VA (Fig. S6). Data from the $m / z \quad 167 \rightarrow 152$ transition is reported here because of the slightly better detection limit.

\section{Results and discussion}

\subsection{Analytical results and data processing}

In this study, 993 samples were analyzed for VA and $p$-HBA (Fig. 2). VA and $p$-HBA levels range from below detection to 0.2 and $0.07 \mathrm{ppb}$, respectively. A substantial fraction of the VA and $p$-HBA data (67 and $58 \%$, respectively) is below the limits of detection. Data below the limits of detection are reported as 0.5 times the limit of detection $(0.003 \mathrm{ppb}$ for VA and $0.006 \mathrm{ppb}$ for $p$-HBA). Smoothing of the data was carried out using time bin averaging (10,40, and 100 year), loess smoothing, and moving averages. All smoothing treatments reveal similar multi-decadal and centennial-scale features in the records and the choice of smoothing technique does not
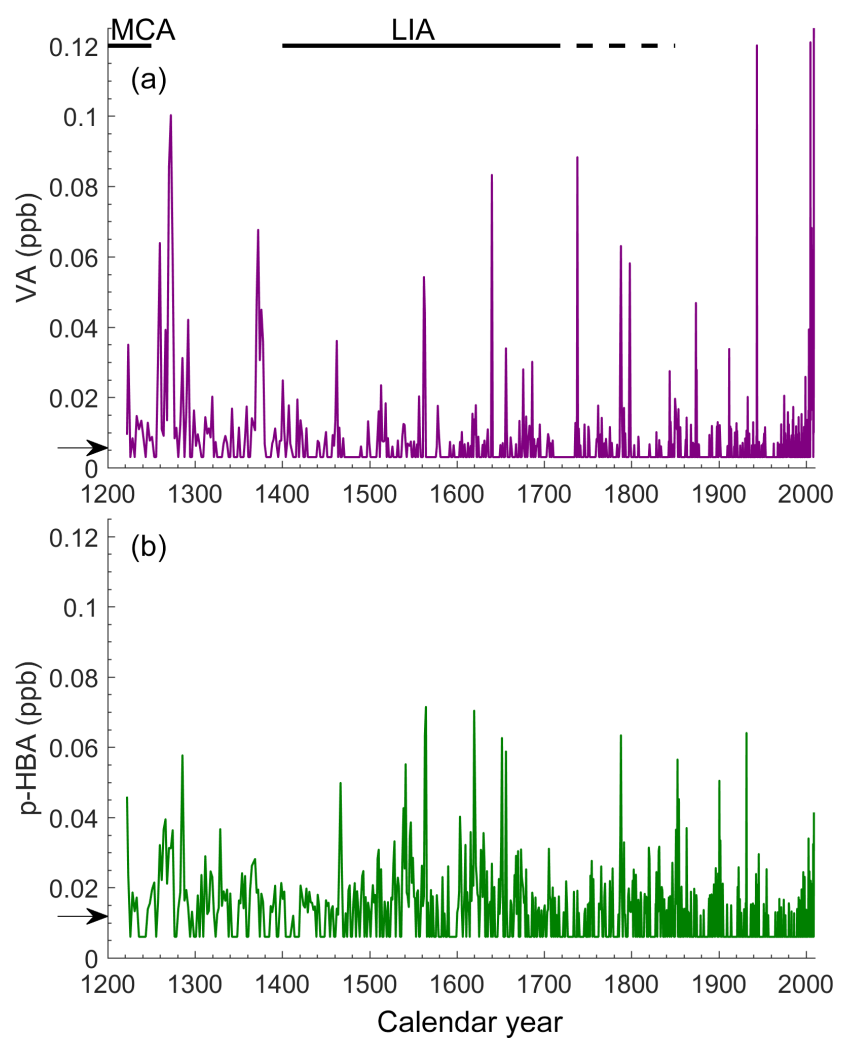

Figure 2. Aromatic acids in the Lomonosovfonna, Svalbard ice core. (a) Vanillic acid, (b) $p$-hydroxybenzoic acid. Arrows are the detection limits. The black horizontal lines are the Medieval Climate Anomaly (MCA) and the Little Ice Age (LIA) (Mann et al., 2009). The dashed horizontal line is the extended LIA in the Svalbard region (Divine et al., 2011).

influence the interpretation of the data (Figs. S7, S8). Geometric means and standard deviations of the transformed data were used for all statistics because frequency distributions of the data show skewness towards lower concentrations. Timeaveraging compensates for the decrease in frequency of sampling with depth in the core due to layer thinning.

\subsection{The Lomonosovfonna vanillic and $p$-hydroxybenzoic acid time series}

The Lomonosovfonna VA and $p$-HBA time series exhibit variability on a wide range of timescales. There is abundant annual to decadal variability in both records. The amplitude of individual peaks in the raw data is roughly similar across the whole record for both compounds, ranging from 0.1 to $1.2 \mathrm{ppb}$ for VA and $0.1-0.8$ for $p$-HBA (Fig. 2). The peaks appear to be of longer duration during the older portions of both records. Both of these aspects of the raw data are likely artifacts due to the combined effect of annual layer thinning with depth and the sampling strategy of analyzing individual ice core samples of constant thickness $(12-16 \mathrm{~cm})$. The time span integrated by individual sam- 

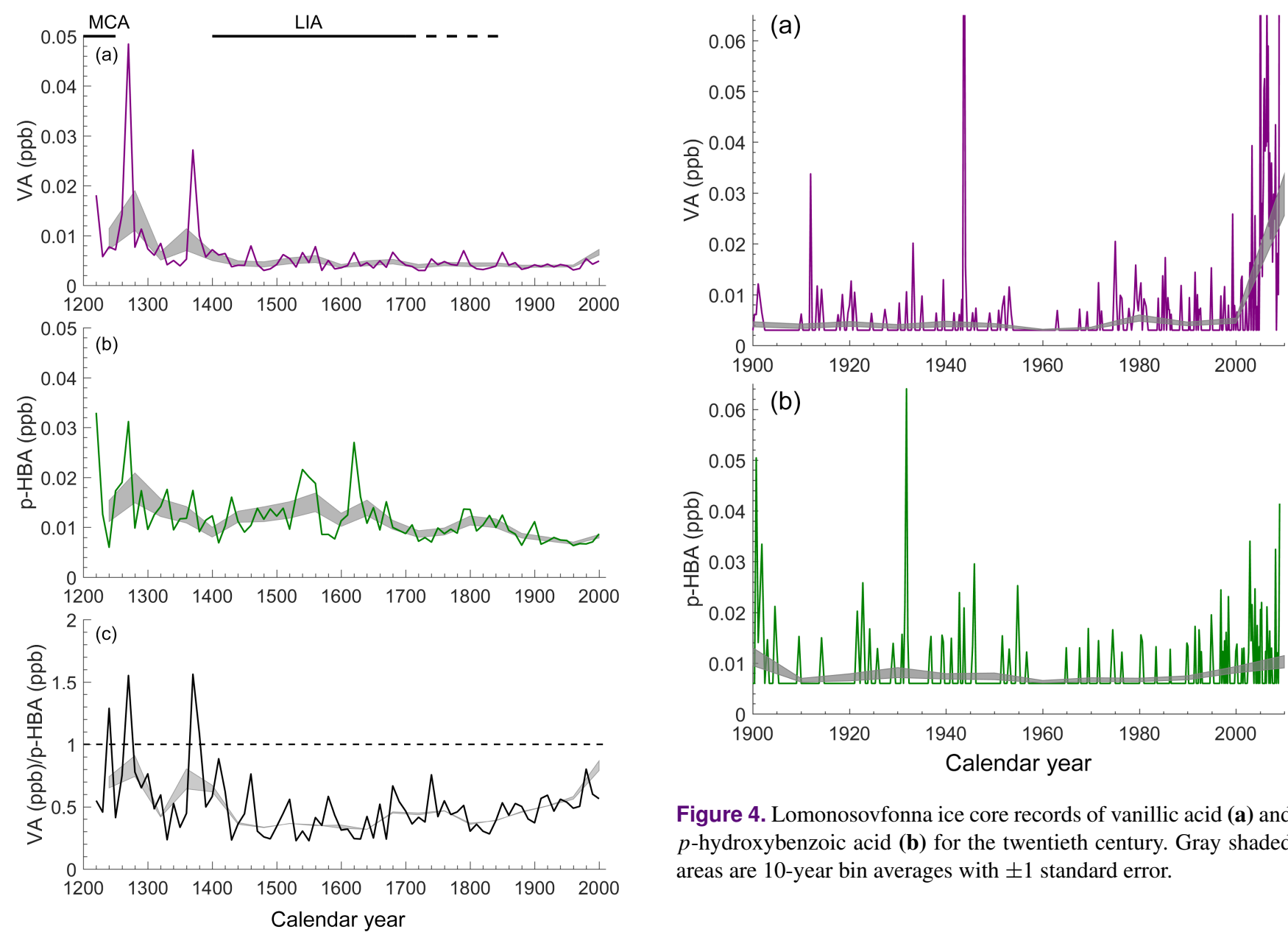

Figure 4. Lomonosovfonna ice core records of vanillic acid (a) and $p$-hydroxybenzoic acid (b) for the twentieth century. Gray shaded areas are 10-year bin averages with \pm 1 standard error.

Figure 3. Lomonosovfonna ice core records of vanillic acid (a) and $p$-hydroxybenzoic acid (b) and the ratio of vanillic acid/ $p$ hydroxybenzoic acid (c). For all plots: solid lines are 10-year bin averages, and gray shaded areas are 40-year bin averages of \pm 1 standard error. The dashed line on the bottom plot indicates a ratio of 1 . The black horizontal lines are the Medieval Climate Anomaly (MCA) and the Little Ice Age (LIA) (Mann et al., 2009). The dashed horizontal line at the top is the extended LIA in the Svalbard region (Divine et al., 2011).

ples ranged from 1.7 years near the bottom of the core, to 0.5 years at mid-depth $(\sim 80 \mathrm{~m})$, to 0.07 years near the top (Fig. S1). This thinning effect is eliminated when the data are time bin-averaged. Peaks in the 10-year bin-averaged records are roughly similar in duration across the whole record (Fig. 3). In the bin-averaged data, the magnitudes of the peaks are no longer constant across the record. For VA, the two early peaks (1250-1280 and 1360-1390 CE) are much larger than all subsequent peaks. $p$-HBA exhibits three major multi-decadal peaks. One is simultaneous with the early VA peak (1250-1280 CE) and the others occur at $1520-1570$ and $1610-1640 \mathrm{CE}$.

Both compounds exhibit long-term decreasing trends over the 800-year record, as illustrated by the 40-year binaveraged data (Fig. 3). Forty-year bin-averaged VA levels decline by about a factor of 3 over the first half of the record (1200-1600 CE), then remain relatively steady for the remainder of the record. It is possible that the decline in VA continued after $1600 \mathrm{CE}$ but much of the data after this time are near or below the limit of detection. Forty-year binaveraged $p$-HBA levels decline by about a factor of 2 over the whole 800-year record.

Centennial-scale variability is observed as pronounced maxima early in the record (1300-1500 CE), as illustrated by the 40-year bin averages (Fig. 3). There are hints of continued centennial-scale variability in VA in the remainder of the record. Centennial-scale variability is evident throughout the $p$-HBA record, with maxima coinciding with the VA maxima early on and with additional maxima in the $1500 \mathrm{~s}$, 1600 s, and 1800s.

The twentieth century levels of VA and $p$-HBA are not anomalous relative to the rest of the ice core record. VA exhibits a slight increase after 1970 and the largest single peak in the record occurs from 2000 to $2008 \mathrm{CE}$ (Fig. 4). $p$-HBA levels also appear to increase after 1970, although to a lesser degree than VA. The 2000-2008 period is slightly elevated 
in $p$-HBA but not to the extent observed in VA. The samples from 1997 to $2009 \mathrm{CE}$ are within the firn layer. It is possible that firn samples could be contaminated with biomass burning aerosols during handling in the field but we have no reason to suspect that the aromatic acids in these samples are influenced by contamination. We have not observed laboratory contamination for these compounds as a significant issue in our laboratory.

Wavelet analysis was used to illustrate temporal variations in the spectral content of the signals. Lomonosovfonna VA and $p$-HBA time series exhibit non-stationary periodic variability, meaning that the spectral characteristics vary with time (Fig. S9).

\subsection{Potential for post-depositional modification of VA and $p$-HBA}

There have been no field studies of atmosphere-snow interactions for aromatic acids like VA and $p$-HBA, so little is known about post-depositional effects. The following three types of effects should be considered: (1) re-volatilization after deposition to the snowpack; (2) vertical redistribution associated with melting, percolation, and refreezing; and (3) degradation due to chemical or microbiological processes. All of these effects would likely occur to a greater extent at relatively warm sites like Lomonosovfonna (mean annual temperature $-12.5^{\circ} \mathrm{C}$ ), and during warmer periods like the Medieval Climate Anomaly (MCA) or the twentieth century. Redistribution associated with melt layers has been discussed in detail for other ions (Wendl et al., 2015), and one would expect that the influence of these processes on aromatic acids would be similar. Wendl et al. (2015) used principal component analysis to determine that melt layers did not have a major influence on the distribution of ions on decadal timescales. Finally, the VA and $p$-HBA data from Lomonosovfonna and Akademii Nauk argue against chemical degradation as an important process, since there is clearly no monotonic decrease in VA or $p$-HBA levels downcore.

The fact that VA and $p$-HBA are commonly observed in atmospheric aerosols, even after long distance transport, suggests that the volatility of these compounds in aerosols might be considerably lower than that of the pure substance (Simoneit and Elias, 2000; Simoneit et al., 2004; Zangrando et al., 2013, 2016). The vapor pressures for VA and $p$-HBA are 0.0023 and $2.5 \times 10^{-5} \mathrm{~Pa}$ (https://chem.nlm. nih.gov/chemidplus/rn/121-34-6, last access: 15 May 2017, Jones, 1960) at $25^{\circ} \mathrm{C}$, respectively. Ionic interactions with salts or hydrophobic interactions with soot or complex organics may stabilize aromatic acids in aerosols or snow. Laboratory and aerosol field studies have demonstrated reduced volatility of low molecular weight organic acids (relative to the vapor pressure of the pure compound) due to interaction with cations derived from sea salt or other sources, but this effect has not been studied for aromatic acids (Häkkinen et al., 2014; Laskin et al., 2012).
If re-volatilization of aromatic acids from the snowpack does occur, one might expect loss to be enhanced in ice acidified by high levels of nitrate and sulfate from volcanic or pollutant inputs. There is no obvious evidence that acidification is a dominant control on VA or $p$-HBA levels in the ice core (Fig. S10). It is particularly notable that VA and $p$-HBA levels are not anomalously low during the twentieth century, when ice core sulfate and nitrate levels increased several fold compared to the preindustrial era (Figs. S10, S11). Based on the ice core signals alone, we conclude that re-volatilization does not appear to be the predominant factor controlling ice core aromatic acid levels, although this cannot be ruled out. Further investigation of this issue is needed.

\subsection{Relationship to ammonium record}

Here we compare the variability of Lomonosovfonna VA and $p$-HBA to the previously published ammonium record from the same ice core (Wendl et al., 2015). That study concluded that prior biogenic sources were the major contributor to ammonium in the ice core prior to the mid-1800s, and agriculture became a major source during the twentieth century. Prior studies have suggested that episodic ammonium peaks in ice cores represent a fire signal, while longer-term variability reflects the biogenic signal (Fischer et al., 2015; Legrand et al., 2016). Following Fischer et al. (2015), we used singular spectrum analysis (SSA) to decompose the Lomonosovfonna VA, $p$-HBA, and ammonium records into these two components.

The analysis was done by computing 30 principle components (PCs) using 3-year bin-averaged data for VA, $p$-HBA, and ammonium (Wendl et al., 2015). The low frequency component (PC-1) of the ammonium record shows little similarity to PC-1 for either of the organic acids. VA and $p$-HBA exhibit decreasing trends over the record while ammonium increases (Fig. 5). To compare the higher frequency components, we used a peak detection method (Higuera et al., 2010). This was done by summing PCs $2-30$ and counting the frequency of peaks above a threshold (75th percentile) in a 40-year moving window. The resulting signals for VA and $p$-HBA exhibit centennial-scale variability which is consistent with that obtained from bin-averaging (Fig. 3) and ammonium exhibits similar variability on these timescales. The correlation coefficient between VA-ammonium and $p$-HBAammonium was computed from the peak frequency data using a 200 -year moving window. The $95 \%$ confidence intervals for these correlation coefficients are shown in Fig. 5. Based on this analysis, ammonium and VA are positively correlated for three time periods (1300-1450, 1675-1725, and post-1880). Ammonium and $p$-HBA exhibit positive correlations for two time periods (1425-1650 and 1825-1875). Interestingly, the positive correlations for ammonium with VA and with $p$-HBA occur at different intervals. The fact that some extended periods of correlation between VA, $p$-HBA, and ammonium are present in the Lomonosovfonna record 
suggests that there may be a fire-derived contribution to the ammonium signal in this ice core. However, the relationships are obviously complex and worthy of further study.

\subsection{Relationship to sedimentary charcoal records}

Sedimentary charcoal records in the Global Charcoal Database (GCD) from Siberia $\left(50-70^{\circ} \mathrm{N}, 50-150^{\circ} \mathrm{E}\right)$ and Fennoscandia $\left(50-70^{\circ} \mathrm{N}, 0-50^{\circ} \mathrm{E}\right)$ were analyzed using the paleofire R package (GCD: Blarquez et al., 2014). Only 3 of the 12 Siberian records in the GCD have sufficient data from 1200 to $2000 \mathrm{CE}$ for comparison to the Lomonosovfonna ice core record. These regions are Chai-ku Lake in eastern Siberia, and Zagas Nuur and Lake Teletskoye in southern Siberia. The Siberian region as a whole is therefore not wellrepresented. Six of the 19 Fennoscandian records in the GCD have enough data from 1200 to $2000 \mathrm{CE}$ for comparison to the Lomonosovfonna ice core record. Siberia and Fennoscandia are primarily boreal tundra woodlands, boreal conifer forests, and boreal mountain systems (Fig. S3; Ruesch and Gibbs, 2008). One important caveat to this comparison is that the dating of sedimentary charcoal records is often based on linear interpolations between a few ${ }^{14} \mathrm{C}$ ages. Hence their age scales are typically less well-constrained than Lomonosovfonna or other ice cores.

Four of the six records from Fennoscandia exhibit increased charcoal influx from 1200 to $1400 \mathrm{CE}$ (Fig. S12; Blarquez et al., 2014). Lomonosovfonna VA and $p$-HBA are both elevated during this period. Three of the six charcoal records are elevated around $1600 \mathrm{CE}$ when Lomonosovfonna $p$-HBA is also elevated. Two of the records also show a long-term decline from 1200 to $2000 \mathrm{CE}$ similar to the Lomonosovfonna VA and $p$-HBA records. Two of the Siberian records exhibited increased charcoal influx from 1200 to $1600 \mathrm{CE}$ relative to $1600 \mathrm{CE}$ to present (Fig. S13). The Lomonosovfonna VA and $p$-HBA are also higher early in the record. The Fennoscandian records are clearly most similar to the Svalbard ice core record, but the database is too limited to determine definitively the source region for the VA and the $p$-HBA in the Lomonosovfonna ice core from so few charcoal records.

\subsection{Comparison between Svalbard and Siberian ice core records of vanillic acid and $p$-hydroxybenzoic acid}

The only other millennial-scale ice core record of VA and $p$-HBA is the Akademii Nauk ice core from the Severnaya Zemlya Archipelago in the Arctic Ocean north of central Siberia (Grieman et al., 2017; Fritzsche et al., 2002). The Akademii Nauk ice core covers a considerably larger time range than Lomonosovfonna, extending over the past 2600 years. Here we discuss only the period of temporal overlap between the two ice cores (1200-2000 CE).
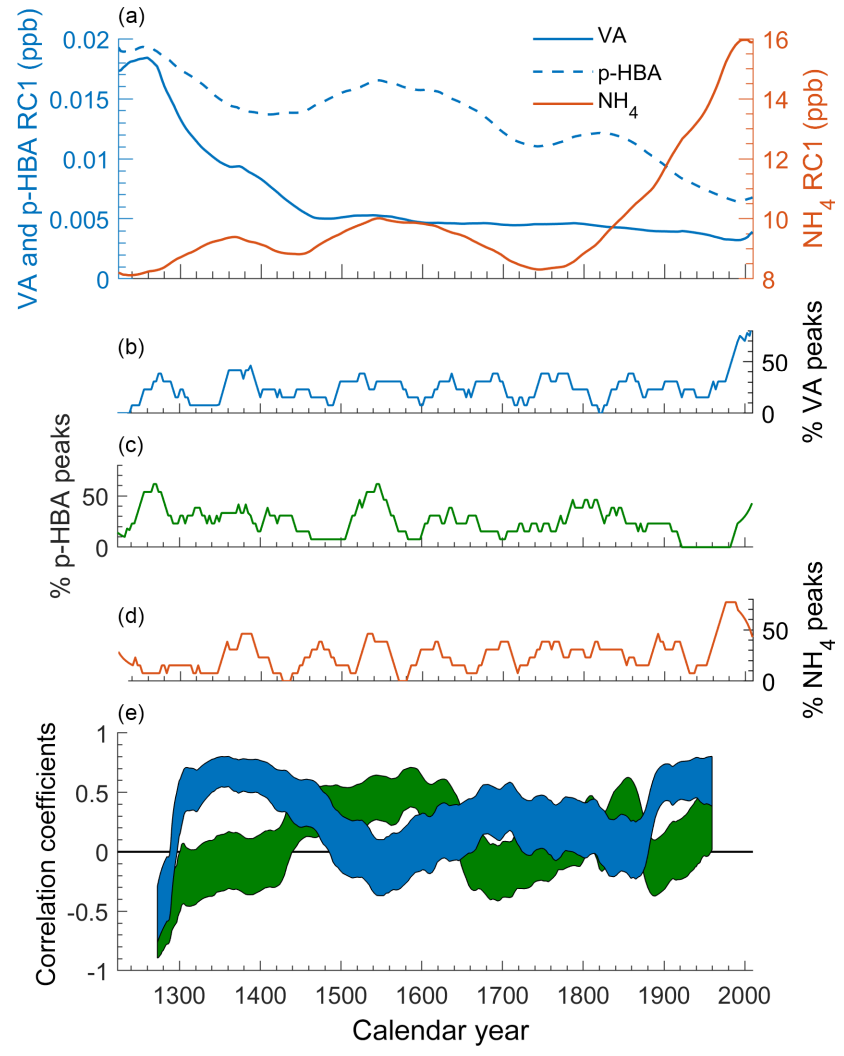

Figure 5. Relationships between Lomonosovfonna vanillic acid (VA), $p$-hydroxybenzoic acid ( $p$-HBA), and ammonium $\left(\mathrm{NH}_{4}\right)$ using 3-year bin-averaged data. (a) First component from the singular spectrum analysis of VA (blue solid line), $p$-HBA (blue dashed line), and $\mathrm{NH}_{4}$ (orange line) (PC1) reconstructed into concentration units $(\mathrm{RC} 1, \mathrm{ppb}),(\mathbf{b}, \mathbf{c}, \mathbf{d})$ Frequency of peaks in the ice core signals reconstructed using singular spectrum components 2-30 and peak threshold of 75th percentile, smoothed with a 40-year running window. (e) Correlation coefficients for the ice core peak frequencies using a 200-year running window $(p<0.001)$. Bands are the $95 \%$ confidence intervals of the correlation coefficients of VA and ammonium (blue) and $p$-HBA and ammonium (green).

The two ice core records exhibit similar trends and levels during the early part of the record (1220-1400 CE; Fig. S14). During this period, Lomonosovfonna exhibits declining levels of both aromatic acids. In the Akademii Nauk core, this period represents the tail end of an earlier peak in both aromatic acids with a maximum around $1200 \mathrm{CE}$. The two cores diverge markedly after $1400 \mathrm{CE}$ for the remainder of the records (Fig. 6). Akademii Nauk VA exhibits a period of highly elevated levels from 1460 to 1660 CE. During this period, Akademii Nauk VA reaches levels more than an order of magnitude above those of Lomonosovfonna VA. Akademii Nauk $p$-HBA exhibits a period of elevated levels from 1460 to 1550 and 1780 to $1860 \mathrm{CE}$. There are multi-decadal peaks in $p$-HBA in the Lomonosovfonna record that overlap in time with the large Akademii Nauk VA peaks, although not nearly 

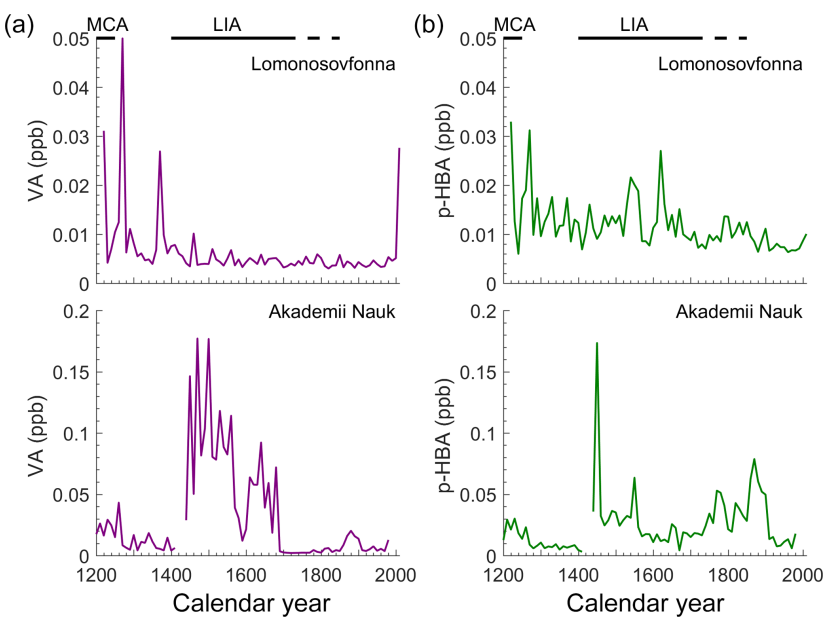

Figure 6. Aromatic acids in the Lomonosovfonna, Svalbard, and Akademii Nauk ice cores. (a) Vanillic acid and (b) $p$ hydroxybenzoic acid. Violet lines are 10-year bin averages of the Lomonosovfonna ice core. Green lines are the 10-year bin averages of the Akademii Nauk ice core measurements (Grieman et al., 2017). The black horizontal lines are the Medieval Climate Anomaly (MCA) and the Little Ice Age (LIA) (Mann et al., 2009). The dashed horizontal line is the extended LIA in the Svalbard region (Divine et al., 2011).

as large in amplitude or duration. Interestingly, these peaks do not appear at all in the Lomonosovfonna VA record.

Ten-day back trajectories were computed for the Akademii Nauk site using the same methods as those described above from 2006 to 2015 CE (Sect. 2.2; Grieman et al., 2017). The trajectories show that both of the Lomonosovfonna and Akademii Nauk sites are influenced by air masses transecting Eurasian forested regions (Fig. 7; Table S1). The largest fraction of trajectories transects Siberian boreal tundra woodland, boreal coniferous forests, and boreal mountain systems for both ice core sites, particularly in the summer and fall. Given this similar transport pattern, we would have expected the two large multi-century peaks in Siberian aromatic acids after $1400 \mathrm{CE}$ to be exhibited in the Lomonosovfonna record as well. The sharp divergence between the two records around $1400 \mathrm{CE}$ and the subsequent dramatic increase in aromatic acids only in the Siberian ice core suggest a change in transport patterns to the sites after $1400 \mathrm{CE}$. The fraction of back trajectories transecting vegetated regions of Siberia for Akademii Nauk was about twice that for Lomonosovfonna. Conversely, trajectories from European forests comprise a smaller contribution to Akademii Nauk than to Lomonosovfonna. Air masses from European regions are more likely to reach the Lomonosovfonna site than the Akademii Nauk site. We speculate that the divergence between the two ice cores reflects a shift in large-scale atmospheric circulation patterns, as discussed below.

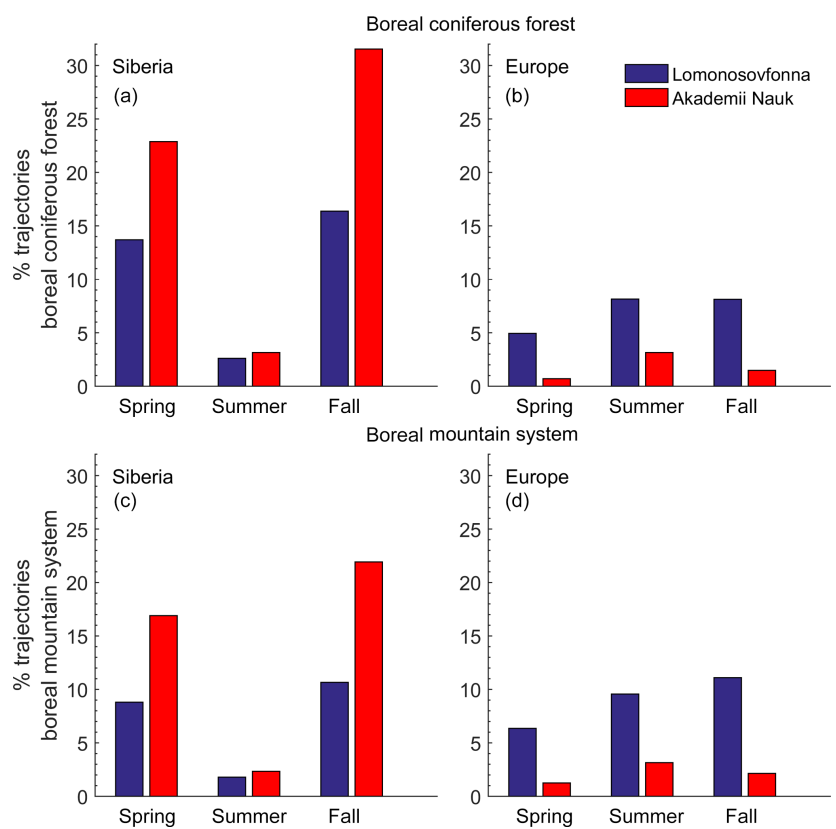

Figure 7. Ten-day back trajectories from 2006 to 2015 reaching the boreal ecosystems starting from the Lomonosovfonna and Akademii Nauk ice core locations. Blue is Lomonosovfonna and red is Akademii Nauk. Trajectories reaching: Siberia (a, c), Europe $(\mathbf{b}, \mathbf{d})$, boreal coniferous forest $(\mathbf{a}, \mathbf{b})$, and boreal mountain system $(\mathbf{c}, \mathbf{d})$.

\subsection{Relationship to atmospheric circulation and climate}

The general climate context for the last millennium is late Holocene cooling, with superimposed centennial-scale climate variability associated with the MCA (950-1250 CE), the LIA (1400-1700 CE), and the twentieth century warming (PAGES 2k Consortium, 2013; Lamb, 1965; Mann et al., 2009). Svalbard $\delta^{18} \mathrm{O}$ ice core records show that cooling continued in the region through the nineteenth century (Divine et al., 2011). Divine et al. (2011) suggest that the extended LIA at Svalbard could reflect the climatic influence of regional sea ice conditions. In that case, the extended LIA was probably not characteristic of the biomass burning source regions in Europe and Siberia influencing the Lomonosovfonna ice core.

For recent decades, increased burning of wildfires is generally associated with higher summer temperatures (Flannigan et al., 2009). On that basis alone, one might expect to see a long-term decrease in aromatic acid signals over the last millennium, and that is generally the case for both VA and $p$-HBA in the Lomonosovfonna ice core. However, on multi-century and centennial timescales, the variability in the aromatic acids in the Lomonosovfonna ice core is also large and somewhat complex. Both VA and $p$-HBA levels were high during the MCA. VA declines into the LIA. $p$-HBA exhibits elevated levels during the latter half of the LIA but VA does not (Fig. 8). This dissimilarity could be due to a shift 
in spatial patterns of either biomass burning or atmospheric transport after $1400 \mathrm{CE}$.

It seems likely that regional changes in burning proxies on multi-century and centennial timescales are strongly linked to changes in large-scale atmospheric circulation and the resulting impacts on regional climate and atmospheric transport. For the source regions influencing the Svalbard Lomonosovfonna ice core, one might expect that changes in the North Atlantic Oscillation (NAO) might play an important role. The NAO is a major mode of climate variability in the North Atlantic region, characterized by changes in the pressure gradient between the Icelandic low and the Azores high during winter months (Hurrell et al., 2001). Strong pressure gradients (positive NAO index) are associated with strong zonal flow, enhanced westerlies transporting warm air to Europe, increased precipitation in northwest Europe, and decreased precipitation in southern Europe (Trouet et al., 2009). Weaker pressure gradients (negative NAO index) are associated with stronger meridional flow and cooling of the North Atlantic region (Trouet et al., 2012). Proxy NAO records have been developed from variations in wintertime sea salt sodium in the GISP2 ice core, from Moroccan tree rings and speleothem records in Scotland, and from lake sediments in southwestern Greenland (Meeker and Mayewski, 2002; Trouet et al., 2009; Olsen et al., 2012).

The proxy NAO records show a marked change in phase at the onset of the LIA (around $1400 \mathrm{CE}$ ) from several hundred years of positive NAO index to a more negative and variable NAO state that continued throughout and after the LIA (Fig. 8). The Lomonosovfonna oxygen isotope $\left(\delta^{18} \mathrm{O}\right)$ record shows a cooling trend at this time, consistent with the NAO shift (Wendl et al., 2015). The change in NAO behavior at this time was accompanied by a decline in VA in the Lomonosovfonna record, a decline in the VA / HBA ratio, and a sudden divergence between the Lomonosovfonna and Akademii Nauk ice cores (1400 CE). We suggest that a change of high latitude northern hemispheric atmospheric circulation patterns occurred at this time, resulting in (1) a cooler, wetter northern Europe with less burning and (2) reduced zonal transport, resulting in "decoupling" of the two ice core signals. Central Siberian burning likely increased at this time, as evidenced by sharply increased aromatic acids in the Akademii Nauk ice core. The Siberian ice core signals are similar in timing to changes in the strength of the Asian monsoon, as recorded in speleothem proxy records (Grieman et al., 2017; Wang et al., 2005). We speculate that during the LIA, central Siberia was influenced primarily by conditions in the Pacific rather than the Atlantic Ocean.

The summertime NAO (SNAO) is defined as the leading mode of July-August sea level pressure (SLP) variability in the North Atlantic sector (Folland et al., 2009; Efthymiadis et al., 2011). The SNAO affects temperatures, precipitation, and cloudiness in Europe during summer, and one might expect that variations in burning are even more directly linked to the SNAO than the NAO. The SNAO has a slightly dif-
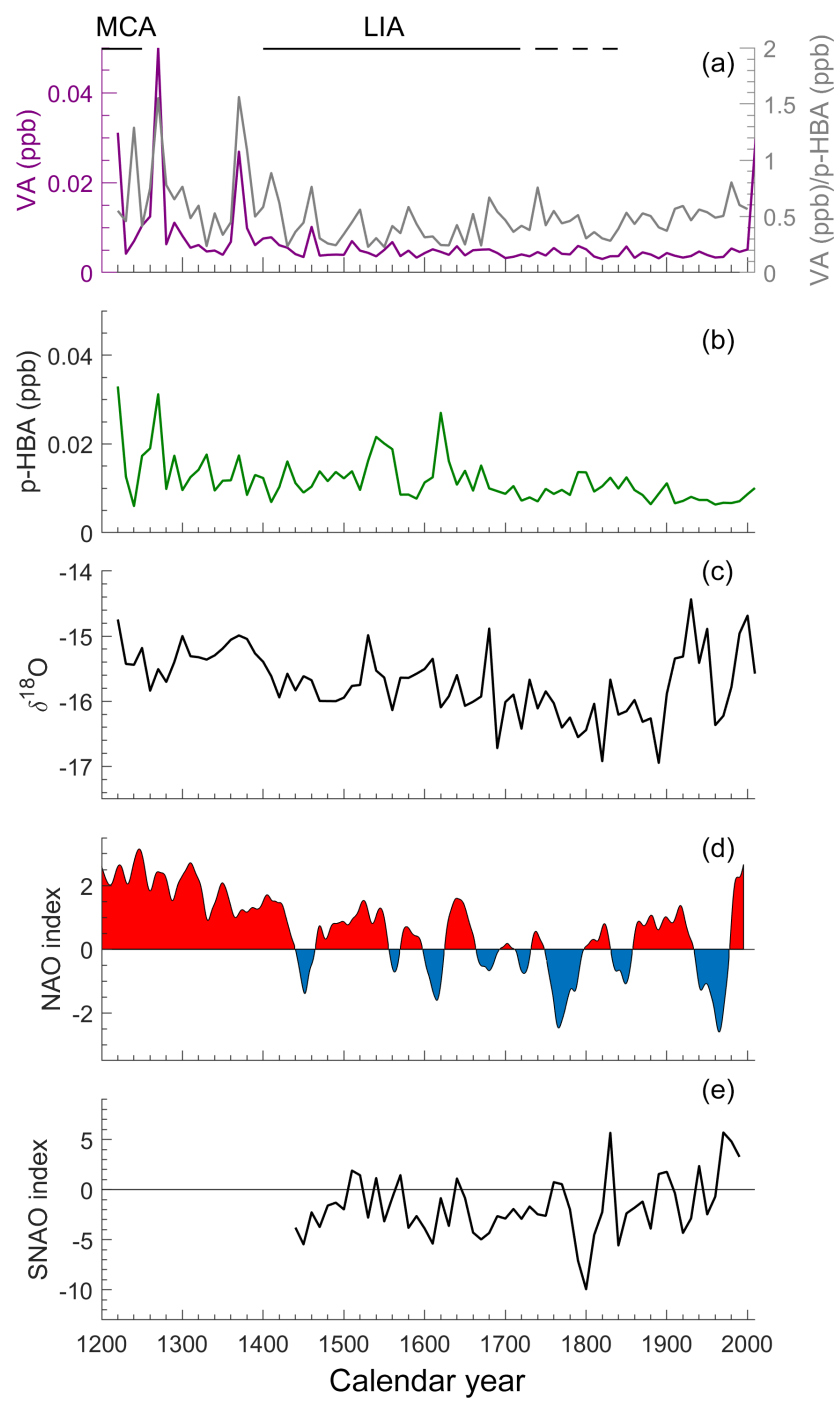

Figure 8. Comparison of the timing of aromatic acid signals in the Lomonosovfonna ice core over the past 800 years compared to other climate-related proxy records. From top: (a) 10-year bin averages of Lomonosovfonna vanillic acid (violet line), ratio of vanillic acid / $p$-hydroxybenzoic acid (gray line), and (b) $p$-hydroxybenxoic acid; (c) 10-year bin averages of the oxygen isotope record from the Lomonosovfonna ice core (Wendl et al., 2015); (d) North Atlantic Oscillation (NAO) index (red > 0; blue < 0; Trouet et al., 2009); and (e) 10-year bin averages of the summer North Atlantic Oscillation (SNAO) index (Linderholm et al., 2009). The black horizontal lines are the timing of the Medieval Climate Anomaly (MCA) and the Little Ice Age (LIA) (Mann et al., 2009). The dashed horizontal line is the extended LIA in the Svalbard region (Divine et al., 2011).

ferent spatial pattern than the NAO, with a relatively small Arctic node and a southern node over northwestern Europe. The positive (negative) mode of the SNAO is characterized by a warmer and drier (cooler, wetter) northern Europe (Linderholm et al., 2008; Folland et al., 2009). The influence of the SNAO extends to central Asia, and could therefore influ- 
ence both major source regions for the Lomonosovfonna ice core.

In order to illustrate the possible influence of the SNAO, we compared back trajectories from the Lomonosovfonna site for recent periods when the SNAO index was positive (1970-1979 CE, mean SNAO index: 6.3) and negative (1948-1957 CE; mean SNAO index: -2.0) (Folland et al., 2009). Figure 9 shows the major spatial clusters of 10-day air mass back trajectories for each time period (computed using HYSPLIT) superimposed on the SLP anomalies relative to mean SLP from 1948 to 2017 . The high SNAO period is characterized by (1) high pressure over Scandinavia, favoring drier conditions, and (2) trajectories generally originating at lower latitudes, with a larger fraction of transport from Scandinavia. These results suggest that SNAO-driven variability in atmospheric transport could contribute to variability in burning signals in the Lomonosovfonna record.

SNAO variability has been reconstructed for the past 500 years using historical documents and tree rings (Linderholm et al., 2008, 2009, 2013; Luterbacher et al., 2001). The SNAO record is primarily negative over the past 500 years, with brief positive excursions until the start of the twentieth century when it shifted into its positive phase (Linderholm et al., 2009). The long-term trends in the SNAO and NAO reconstructions are generally similar, and there are some common features on centennial timescales (Fig. 8; Trouet et al., 2009). Both NAO and SNAO records exhibit a positive excursion from 1500 to $1650 \mathrm{CE}$, during a period of elevated $p$ HBA in Lomonosovfonna. After $1400 \mathrm{CE}$, VA remains low and does not show similar variability to $p$-HBA. This incoherence between the records could be due to the change in atmospheric circulation patterns after $1400 \mathrm{CE}$ when the Svalbard and Siberia ice core records diverge.

\subsection{Lomonosovfonna ice core VA / p-HBA ratios}

The mean VA / p-HBA ratio for the Lomonosovfonna ice core using the 10-year bin averages of each record is $0.40 \pm$ 0.25 ( $n=79)$. Both compounds are produced during the smoldering phase of burning (Akagi et al., 2011; Legrand et al., 2016; Simoneit, 2002) and both are produced from combustion of major boreal forest tree species. Short-term changes in the ratio most likely reflect the changing contributions from various source regions with different ecosystems. Longer-term changes in the ratio could reflect changes in ecology and biogeography (i.e., shifts between conifer and broadleaf forests or grasslands) or changes in atmospheric transport patterns. As noted earlier, analysis of back trajectories suggests that boreal forests are the principle source regions for this ice core, with minor contributions from tundra and temperate forests.

The range of VA/p-HBA ratios observed in the Lomonosovfonna ice core is consistent with the laboratory combustion studies of boreal forest tree species. Combustion studies have been conducted on several conifers char-

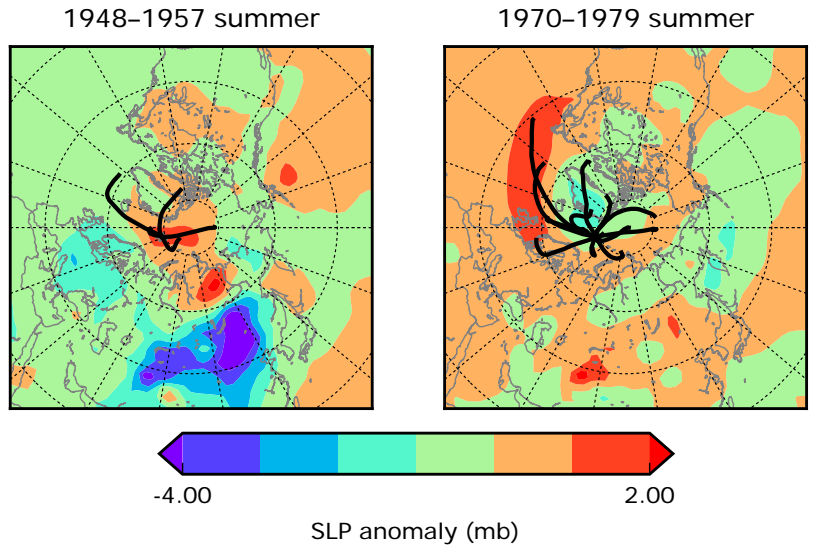

Figure 9. Ten-day clustered back trajectories starting from the Lomonosovfonna ice core location superimposed on sea level pressure anomalies for summer (June-August) of 1948-1957 (negative SNAO) and 1970-1979 (positive SNAO). Anomalies are relative to the 1948-2017 mean of NCEP/NCAR reanalysis data.

acteristic of North American and European boreal forests. North American conifer (lodgepole pine, Sitka spruce, Douglas fir, and mountain hemlock) combustion yielded VA / $p$ HBA weight ratios ranging from 0.40 to 0.99 (Oros and Simoneit, 2001a) (Table S2). Specific North American conifers produce only one of the two compounds. For example, eastern white pine produced only VA, and noble fir produced only $p$-HBA (Oros and Simoneit, 2001a). European conifers and peat burning produced VA / $p$-HBA weight ratios ranging from 0.07 to 8.75 (Iinuma et al., 2007). Combustion of a German peat sample yielded a low VA / $p$-HBA ratio of 0.08 (Iinuma et al., 2007; Oros et al., 2006). Combustion of a tundra grass sample from the Canadian Yukon produced $p$-HBA only, but at rates 1000-fold less than conifers (Oros et al., 2006). Deciduous tree species produced roughly 1000-fold more VA than conifers (mg VA kg-1 fuel burned), and deciduous species did not produce detectable levels of $p$-HBA (Oros and Simoneit, 2001a, b). Thus even a small fraction of air mass trajectories from temperate forests could influence the VA / $p$-HBA ratio.

We are not aware of laboratory combustion studies of the actual species comprising Siberian forests or tundra. This is a major gap in the knowledge base needed to interpret Arctic ice core data. Similarly, very few studies to date have reported VA / $p$-HBA ratios for ambient Arctic aerosols. Fu et al. (2009) reported ratios ranging from 0.16 to 2.2 in weekly aerosol samples collected at Alert, covering the range observed in the ice core.

There are significant long-term changes in the Lomonosovfonna VA/p-HBA ratio over time. The ratio is relatively high during the MCA (0.8), decreases by a factor of 2 from 1200 to $1400 \mathrm{CE}$, and remains low through the LIA until around $1800 \mathrm{CE}$ (Fig. 3). There is also an increase in VA/ $p$-HBA after 1800, although VA 
is close to the detection limit and the uncertainty in the ratio is consequently large. Interestingly, the changes in the VA / $p$-HBA ratio broadly mirror changes in the phase of the paleoreconstructions of the NAO and SNAO (Fig. 8). One might speculate that the associated changes in climate and transport mentioned earlier contribute to the variations in the VA / $p$-HBA ratio but the specific causes are not understood at this time.

There are several multi-decadal excursions in the VA / $p$ HBA ratio. Ratios greater than one occur in the VA peaks around 1270 and $1370 \mathrm{CE}$. The second of these peaks is a notable increase in VA, with no corresponding peak in $p$ HBA. Conversely, around 1540 and $1620 \mathrm{CE}$, there are $p$ HBA peaks without a corresponding peak in the VA record. These events are probably too short to represent ecological changes, but too long to represent single fire events or seasons. Such events are worthy of further investigation.

\section{Conclusions}

The Lomonosovfonna ice core record shows that the pyrogenic aromatic acids, vanillic acid and para-hydroxybenzoic acid, are present in Arctic ice and preserved on millennial timescales. The observed temporal variability of these signals should contain information about the history of high latitude burning in northern Europe and Siberia. VA and $p$-HBA are both elevated from 1200 to $1400 \mathrm{CE}$ and decline until the LIA. Paleoclimate proxy records indicate that this transition coincides with a shift in the North Atlantic Oscillation from positive to a more negative state, but the causal basis for a relationship is not established.

On centennial and shorter timescales, the two acids exhibit some notable differences. For example, the two largest peaks in the $p$-HBA record around $1600 \mathrm{CE}$ are not present in the VA record. Conversely, elevated levels of VA from 2000 to $2008 \mathrm{CE}$ are not present in the $p$-HBA record. Such anomalies are intriguing in that they suggest significant changes in either burning patterns or atmospheric transport. Further studies of the variability of these compounds in ice cores covering the instrumental and satellite eras should be conducted.

The two millennial-scale ice cores analyzed for these compounds to date, Lomonosovfonna and Akademii Nauk, show intriguing similarity between the Svalbard and Siberian records at the end of the MCA (1200-1400 CE) but dramatic differences for most of the past millennium. Such differences are surprising given that air mass trajectories based on reanalysis data indicate considerable overlap in source areas for the two ice cores. It seems that a large-scale dynamical explanation of the regional and temporal trends must exist in these and other proxy fire records. Developing a unified interpretation of these signals will require further work.
Data availability. The data reported in this article were submitted to the NSF Artic Data Center (http://arcticdata.io/) before publication (Grieman, 2018).

Author contributions. MG, MA, and ES developed the analytical method. MG combined and measured the ice core melt samples used in this study and processed the data. MG and ES wrote the manuscript. MS and her team drilled and processed the ice core, provided samples, developed the depth-age scale, and provided comments on the manuscript. EI initiated the Lomonosovfonna ice core drilling project, was responsible for field logistics, and provided comments on the manuscript. MA provided comments on the manuscript.

Competing interests. The authors declare that they have no conflict of interest.

Acknowledgements. NCEP/NCAR reanalysis data were accessed from: ftp://arlftp.arlhq.noaa.gov/pub/archives/reanalysis. We would like to acknowledge Sabina Brütsch and Michael Sigl for assistance with collecting ice core melt samples, Cyril McCormick for help with instrument maintenance, and Tyler Sutterley and Ashley Payne for help with coding. We would also like to acknowledge research support by a generous donation from the Jenkins Family to the Department of Earth System Science, University of California, Irvine. Funding was also provided by the National Science Foundation (ANT-0839122; PLR-1142517) and by the NSF Independent Research/Development program. Wavelet software was provided by Christopher Torrence and Gilbert P. Compo (http://paos.colorado.edu/research/wavelets/; Torrence and Compo, 1998). The Global Charcoal Database was accessed at: http://gpwg.paleofire.org.

Edited by: Carlo Barbante

Reviewed by: Legrand Michel and two anonymous referees

\section{References}

Akagi, S. K., Yokelson, R. J., Wiedinmyer, C., Alvarado, M. J., Reid, J. S., Karl, T., Crounse, J. D., and Wennberg, P. O.: Emission factors for open and domestic biomass burning for use in atmospheric models, Atmos. Chem. Phys., 11, 4039-4072, https://doi.org/10.5194/acp-11-4039-2011, 2011.

Beaudon, E., Moore, J. C., Martma, T., Pohjola, V. A., Van De Wal, R. S., Kohler, J., and Isaksson, E.: Lomonosovfonna and Holtedahlfonna ice cores reveal eastwest disparities of the Spitsbergen environment since AD 1700, J. Glaciol., 59, 1069-1083, https://doi.org/10.3189/2013JoG12J203, 2013.

Blarquez, O., Vannière, B., Marlon, J. R., Daniau, A.-L., Power, M. J., Brewer, S., and Bartlein, P. J.: Paleofire: An R package to analyse sedimentary charcoal records from the Global Charcoal Database to reconstruct past biomass burning, Comput. Geosci., 72, 255-261, https://doi.org/10.1016/j.cageo.2014.07.020, 2014.

Bouwman, A. F., Lee, D. S., Asman, W. A. H., Dentener, F. J., Van Der Hoek, K. W., and Olivier, J. G. J.: A global high-resolution 
emission inventory for ammonia, Global Biogeochem. Cy., 11, 561-587, https://doi.org/10.1029/97GB02266, 1997.

Bowman, D. M., Balch, J. K., Artaxo, P., Bond, W. J., Carlson, J. M., Cochrane, M. A., D’Antonio, C. M., DeFries, R. S., Doyle, J. C., Harrison, S. P., Johnston, F. H., Keeley, J. E., Krawchuk, M. A., Kull17, C. A., Marston18, J. B., Moritz, M. A., Prentice, I. C., Roos, C. I., Scott, A. C., Swetnam, T. W., van der Werf, G. R., Pyne, S. J.: Fire in the Earth system, Science, 324, 481-484, https://doi.org/10.1126/science.1163886, 2009.

Chapin, F. S., Mcguire, A. D., Randerson, J., Pielke, R., Baldocchi, D., Hobbie, S. E., Roulet, N., Eugster, W., Kasischke, E., Rastetter, E. B., Zimov, S. A., and Running, S. W.: Arctic and boreal ecosystems of western North America as components of the climate system, Glob. Change Biol., 6, 211-223, https://doi.org/10.1046/j.1365-2486.2000.06022.x, 2000.

Crutzen, P. J. and Andreae, M. O.: Biomass Burning in the Tropics: Impact on Atmospheric Chemistry and Biogeochemical Cycles, Science, 250, 1669-1678, https://doi.org/10.1126/science.250.4988.1669, 1990.

Divine, D., Isaksson, E., Martma, T., Meijer, H. A., Moore, J., Pohjola, V., van de Wal, R. S. W., and Godtliebsen, F.: Thousand years of winter surface air temperature variations in Svalbard and northern Norway reconstructed from ice-core data, Polar Res., 30, 7379, https://doi.org/10.3402/polar.v30i0.7379, 2011.

Draxler, R. R., Stunder, B., Rolph, G., and Taylor, A.: HYSPLIT4 user's guide, US Department of Commerce, National Oceanic and Atmospheric Administration, Environmental Research Laboratories, Air Resources Laboratory, 1999.

Efthymiadis, D., Goodess, C. M., and Jones, P. D.: Trends in Mediterranean gridded temperature extremes and large-scale circulation influences, Nat. Hazards Earth Syst. Sci., 11, 21992214, https://doi.org/10.5194/nhess-11-2199-2011, 2011.

Eichler, A., Brütsch, S., Olivier, S., Papina, T., and Schwikowski, M.: A 750 year ice core record of past biogenic emissions from Siberian boreal forests, Geophys. Res. Lett., 36, L18813, https://doi.org/10.1029/2009GL038807, 2009.

Ferretti, D. F., Miller, J. B., White, J. W. C., Etheridge, D. M., Lassey, K. R., Lowe, D. C., Meure, C. M. M., Dreier, M. F., Trudinger, C. M., van Ommen, T. D., and Langenfelds, R. L.: Unexpected Changes to the Global Methane Budget over the Past 2000 Years, Science, 309, 1714-1717, https://doi.org/10.1126/science.1115193, 2005.

Fischer, H., Schüpbach, S., Gfeller, G., Bigler, M., Röthlisberger, R., Erhardt, T., Stocker, T. F., Mulvaney, R., and Wolff, E. W.: Millennial changes in North American wildfire and soil activity over the last glacial cycle, Nat. Geosci., 8, 723-727, https://doi.org/10.1038/ngeo2495, 2015.

Flannigan, M. D., Krawchuk, M. A., de Groot, W. J., Wotton, B. M., and Gowman, L. M.: Implications of changing climate for global wildland fire, Int. J. Wildland Fire, 18, 483-507, https://doi.org/10.1071/WF08187, 2009.

Folland, C. K., Knight, J., Linderholm, H. W., Fereday, D., Ineson, S., and Hurrell, J. W.: The summer North Atlantic Oscillation: past, present, and future, J. Climate, 22, 1082-1103, https://doi.org/10.1175/2008JCLI2459.1, 2009.

Fritzsche, D., Wilhelms, F., Savatyugin, L. M., Pinglot, J. F., Meyer, H., Hubberten, H.-W., and Miller, H.: A new deep ice core from Akademii Nauk ice cap, Severnaya Zemlya,
Eurasian Arctic: first results, Ann. Glaciol., 35, 25-28, https://doi.org/10.3189/172756402781816645, 2002.

Fu, P., Kawamura, K., and Barrie, L. A.: Photochemical and Other Sources of Organic Compounds in the Canadian High Arctic Aerosol Pollution during Winter-Spring, Environ. Sci. Technol., 43, 286-292, https://doi.org/10.1021/es803046q, 2009.

Fuhrer, K., Neftel, A., Anklin, M., Staffelbach, T., and Legrand, M.: High-resolution ammonium ice core record covering a complete glacial-interglacial cycle, J. Geophys. Res., 101, 41474164, https://doi.org/10.1029/95JD02903, 1996.

Gambaro, A., Zangrando, R., Gabrielli, P., Barbante, C., and Cescon, P.: Direct Determination of Levoglucosan at the Picogram per Milliliter Level in Antarctic Ice by HighPerformance Liquid Chromatography/Electrospray Ionization Triple Quadrupole Mass Spectrometry, Anal. Chem., 80, 16491655, https://doi.org/10.1021/ac701655x, 2008.

Grannas, A. M., Shepson, P. B., and Filley, T. R.: Photochemistry and nature of organic matter in Arctic and Antarctic snow, Global Biogeochem. Cy., 18, GB1006, https://doi.org/10.1029/2003GB002133, 2004.

Grieman, M.: Ice core vanillic acid and para-hydroxybenzoic acid concentrations, Lomonosovfonna, Svalbard, Norway, 12222009, Arctic Data Center, https://doi.org/10.18739/A2Q572, last access: May 2018.

Grieman, M. M., Aydin, M., Fritzsche, D., McConnell, J. R., Opel, T., Sigl, M., and Saltzman, E. S.: Aromatic acids in a Eurasian Arctic ice core: a 2600-year proxy record of biomass burning, Clim. Past, 13, 395-410, https://doi.org/10.5194/cp-13-3952017, 2017.

Häkkinen, S. A. K., McNeill, V. F., and Riipinen, I.: Effect of Inorganic Salts on the Volatility of Organic Acids, Environ. Sci. Technol., 48, 13718-13726, https://doi.org/10.1021/es5033103, 2014.

Hennigan, C. J., Sullivan, A. P., Collett, J. L., and Robinson, A. L.: Levoglucosan stability in biomass burning particles exposed to hydroxyl radicals, Geophys. Res. Lett., 37, L09806, https://doi.org/10.1029/2010GL043088, 2010.

Hessl, A. E.: Pathways for climate change effects on fire: Models, data, and uncertainties, Prog. Phys. Geog., 35, 393-407, https://doi.org/10.1177/0309133311407654, 2011.

Hicks, S. and Isaksson, E.: Assessing source areas of pollutants from studies of fly ash, charcoal, and pollen from Svalbard snow and ice, J. Geophys. Res., 111, D02113, https://doi.org/10.1029/2005JD006167, 2006.

Higuera, P. E., Gavin, D. G., Bartlein, P. J., and Hallett, D. J.: Peak detection in sediment-charcoal records: impacts of alternative data analysis methods on fire-history interpretations, Int. J. Wildland Fire, 19, 996-1014, https://doi.org/10.1071/WF09134, 2010.

Hoffmann, D., Tilgner, A., Iinuma, Y., and Herrmann, H.: Atmospheric stability of levoglucosan: a detailed laboratory and modeling study, Environ. Sci. Technol., 44, 694-699, https://doi.org/10.1021/es902476f, 2010.

Hunter, J. D.: Matplotlib: A 2D Graphics Environment, Comput. Sci. Eng., 9, 90-95, https://doi.org/10.1109/MCSE.2007.55, 2007.

Hurrell, J. W., Kushnir, Y., and Visbeck, M.: The North Atlantic Oscillation, Science, 291, 603-605, https://doi.org/10.1126/science.1058761, 2001. 
Iinuma, Y., Brüggemann, E., Gnauk, T., Müller, K., Andreae, M. O., Helas, G., Parmar, R., and Herrmann, H.: Source characterization of biomass burning particles: The combustion of selected European conifers, African hardwood, savanna grass, and German and Indonesian peat, J. Geophys. Res., 112, D08209, https://doi.org/10.1029/2006JD007120, 2007.

Jones, A. H.: Sublimation Pressure Data for Organic Compounds, J. Chem. Eng. Data, 5, 196-200, 1960.

Kalnay, E., Kanamitsu, M., Kistler, R., Collins, W., Deaven, D., Gandin, L., Iredell, M., Saha, S., White, G., Woollen, J., Zhu, Y., Leetmaa, A., Reynolds, B., Chelliah, M., Ebisuzaki, W., Higgins, W., Janowiak, J., Mo, K., Ropelewski, C., Wang, J., Jenne, R., and Joseph, D.: The NCEP/NCAR 40-Year Reanalysis Project, B. Am. Meteorol. Soc., 77, 437-471, 1996.

Kawamura, K., Izawa, Y., Mochida, M., and Shiraiwa, T.: Ice core records of biomass burning tracers (levoglucosan and dehydroabietic, vanillic and p-hydroxybenzoic acids) and total organic carbon for past 300 years in the Kamchatka Peninsula, Northeast Asia, Geochim. Cosmochim. Ac., 99, 317-329, https://doi.org/10.1016/j.gca.2012.08.006, 2012.

Lamb, H.: The early medieval warm epoch and its sequel, Palaeogeogr. Palaeocl., 1, 13-37, https://doi.org/10.1016/00310182(65)90004-0, 1965

Laskin, A., Moffet, R. C., Gilles, M. K., Fast, J. D., Zaveri, R. A., Wang, B., Nigge, P., and Shutthanandan, J.: Tropospheric chemistry of internally mixed sea salt and organic particles: Surprising reactivity of $\mathrm{NaCl}$ with weak organic acids, J. Geophys. Res., 117, D15302, https://doi.org/10.1029/2012JD017743, 2012.

Legrand, M., De Angelis, M., Staffelbach, T., Neftel, A., and Stauffer, B.: Large perturbations of ammonium and organic acids content in the summit-Greenland Ice Core. Fingerprint from forest fires?, Geophys. Res. Lett., 19, 473-475, https://doi.org/10.1029/91GL03121, 1992.

Legrand, M., McConnell, J., Fischer, H., Wolff, E. W., Preunkert, S., Arienzo, M., Chellman, N., Leuenberger, D., Maselli, O., Place, P., Sigl, M., Schüpbach, S., and Flannigan, M.: Boreal fire records in Northern Hemisphere ice cores: a review, Clim. Past, 12, 2033-2059, https://doi.org/10.5194/cp-12-2033-2016, 2016.

Linderholm, H. W., Folland, C., and Hurrell, J.: Reconstructing Summer North Atlantic Oscillation (SNAO) variability over the last five centuries, Tree rings in archaeology, Clim. Ecol., 6, 816, https://doi.org/10.2312/GFZ.b103-08056, 2008.

Linderholm, H. W., Folland, C. K., and Walther, A.: A multicentury perspective on the summer North Atlantic Oscillation (SNAO) and drought in the eastern Atlantic Region, J. Quaternary Sci., 24, 415-425, https://doi.org/10.1002/jqs.1261, 2009.

Linderholm, H. W., Seim, A., Ou, T., Jeong, J.-H., Liu, Y., Wang, X., Bao, G., and Folland, C.: Exploring teleconnections between the summer NAO (SNAO) and climate in East Asia over the last four centuries - A tree-ring perspective, Dendrochronologia, 31, 297-310, https://doi.org/10.1016/j.dendro.2012.08.004, 2013.

Luterbacher, J., Xoplaki, E., Dietrich, D., Jones, P. D., Davies, T. D., Portis, D., Gonzalez-Rouco, J. F., von Storch, H., Gyalistras, D., Casty, C., and Wanner, H.: Extending North Atlantic oscillation reconstructions back to 1500, Atmos. Sci. Lett., 2, 114-124, https://doi.org/10.1006/asle.2002.0047, 2001.

Mack, M. C., Bret-Harte, M. S., Hollingsworth, T. N., Jandt, R. R., Schuur, E. A. G., Shaver, G. R., and Verbyla, D. L.: Carbon loss from an unprecedented Arctic tundra wildfire, Nature, 475, 489492, https://doi.org/10.1038/nature10283, 2011.

Mann, M. E., Zhang, Z., Rutherford, S., Bradley, R. S., Hughes, M. K., Shindell, D., Ammann, C., Faluvegi, G., and Ni, F.: Global Signatures and Dynamical Origins of the Little Ice Age and Medieval Climate Anomaly, Science, 326, 1256-1260, https://doi.org/10.1126/science.1177303, 2009.

Marlon, J. R., Bartlein, P. J., Carcaillet, C., Gavin, D. G., Harrison, S. P., Higuera, P. E., Joos, F., Power, M. J., and Prentice, I. C.: Climate and human influences on global biomass burning over the past two millennia, Nat. Geosci., 1, 697-702, https://doi.org/10.1038/ngeo313, 2008.

Marlon, J. R., Kelly, R., Daniau, A.-L., Vannière, B., Power, M. J., Bartlein, P., Higuera, P., Blarquez, O., Brewer, S., Brücher, T., Feurdean, A., Romera, G. G., Iglesias, V., Maezumi, S. Y., Magi, B., Courtney Mustaphi, C. J., and Zhihai, T.: Reconstructions of biomass burning from sediment-charcoal records to improve data-model comparisons, Biogeosciences, 13, 3225-3244, https://doi.org/10.5194/bg-13-3225-2016, 2016.

McConnell, J. R., Edwards, R., Kok, G. L., Flanner, M. G., Zender, C. S., Saltzman, E. S., Banta, J. R., Pasteris, D. R., Carter, M. M., and Kahl, J. D. W.: 20th-Century Industrial Black Carbon Emissions Altered Arctic Climate Forcing, Science, 317, 1381-1384, https://doi.org/10.1126/science.1144856, 2007.

Meeker, L. D. and Mayewski, P. A.: A 1400-year highresolution record of atmospheric circulation over the North Atlantic and Asia, The Holocene, 12, 257-266, https://doi.org/10.1191/0959683602hl542ft, 2002.

Müller-Tautges, C., Eichler, A., Schwikowski, M., Pezzatti, G. B., Conedera, M., and Hoffmann, T.: Historic records of organic compounds from a high Alpine glacier: influences of biomass burning, anthropogenic emissions, and dust transport, Atmos. Chem. Phys., 16, 1029-1043, https://doi.org/10.5194/acp-161029-2016, 2016.

Olsen, J., Anderson, N. J., and Knudsen, M. F.: Variability of the North Atlantic Oscillation over the past 5,200 years, Nat. Geosci., 5, 808-812, 2012.

Oros, D. R. and Simoneit, B. R. T.: Identification and emission factors of molecular tracers in organic aerosols from biomass burning Part 1. Temperate climate conifers, Appl. Geochem., 16, 1513-1544, https://doi.org/10.1016/s0883-2927(01)00021$\mathrm{x}, 2001 \mathrm{a}$.

Oros, D. R. and Simoneit, B. R. T.: Identification and emission factors of molecular tracers in organic aerosols from biomass burning Part 2. Deciduous trees, Appl. Geochem., 16, 1545-1565, https://doi.org/10.1016/S0883-2927(01)00022-1, 2001b.

Oros, D. R., Abas, M. R. b., Omar, N. Y. M. J., Rahman, N. A., and Simoneit, B. R. T.: Identification and emission factors of molecular tracers in organic aerosols from biomass burning: Part 3. Grasses, Appl. Geochem., 21, 919-940, https://doi.org/10.1016/j.apgeochem.2006.01.008, 2006.

PAGES 2k Consortium: Continental-scale temperature variability during the past two millennia, Nat. Geosci., 6, 339-346, https://doi.org/10.1038/ngeo1797, 2013.

Pohjola, V. A., Moore, J. C., Isaksson, E., Jauhiainen, T., van de Wal, R. S. W., Martma, T., Meijer, H. A. J., and Vaikmäe, R.: Effect of periodic melting on geochemical and isotopic signals in an ice core from Lomonosovfonna, Svalbard, J. Geophys. Res., 107, 
ACL 1-1-ACL 1-14, https://doi.org/10.1029/2000JD000149, 2002.

Power, M., Marlon, J., Ortiz, N., Bartlein, P., Harrison, S., Mayle, F., Ballouche, A., Bradshaw, R., Carcaillet, C., Cordova, C., Mooney, S., Moreno, P., Prentice, I., Thonicke, K., Tinner, W., Whitlock, C., Zhang, Y., Zhao, Y., Ali, A., Anderson, R., Beer, R., Behling, H., Briles, C., Brown, K., Brunelle, A., Bush, M., Camill, P., Chu, G., Clark, J., Colombaroli, D., Connor, S., Daniau, A. L., Daniels, M., Dodson, J., Doughty, E., Edwards, M., Finsinger, W., Foster, D., Frechette, J., Gaillard, M. J., Gavin, D., Gobet, E., Haberle, S., Hallett, D., Higuera, P., Hope, G., Horn, S., Inoue, J., Kaltenrieder, P., Kennedy, L., Kong, Z., Larsen, C., Long, C., Lynch, J., Lynch, E., McGlone, M., Meeks, S., Mensing, S., Meyer, G., Minckley, T., Mohr, J., Nelson, D., New, J., Newnham, R., Noti, R., Oswald, W., Pierce, J., Richard, P., Rowe, C., Sanchez Goñi, M., Shuman, B., Takahara, H., Toney, J., Turney, C., Urrego-Sanchez, D., Umbanhowar, C., Vandergoes, M., Vanniere, B., Vescovi, E., Walsh, M., Wang, X., Williams, N., Wilmshurst, J., and Zhang, J.: Changes in fire regimes since the Last Glacial Maximum: an assessment based on a global synthesis and analysis of charcoal data, Climate Dynamics, 30, 887-907, https://doi.org/10.1007/s00382-007-0334$\mathrm{x}, 2008$.

Power, M., Mayle, F., Bartlein, P., Marlon, J., Anderson, R., Behling, H., Brown, K., Carcaillet, C., Colombaroli, D., Gavin, D., Hallett, D., Horn, S., Kennedy, L., Lane, C., Long, C., Moreno, P., Paitre, C., Robinson, G., Taylor, Z., and Walsh, M.: Climatic control of the biomass-burning decline in the Americas after $\mathrm{AD} 1500$, The Holocene, 23, 3-13, https://doi.org/10.1177/0959683612450196, 2013.

Randerson, J. T., Liu, H., Flanner, M. G., Chambers, S. D., Jin, Y., Hess, P. G., Pfister, G., Mack, M. C., Treseder, K. K., Welp, L. R., Chapin, F. S., Harden, J. W., Goulden, M. L., Lyons, E., Neff, J. C., Schuur, E. A. G., and Zender, C. S.: The Impact of Boreal Forest Fire on Climate Warming, Science, 314, 1130-1132, https://doi.org/10.1126/science.1132075, 2006.

Rubino, M., D’Onofrio, A., Seki, O., and Bendle, J. A.: Ice-core records of biomass burning, The Anthropocene Review, 3, 140162, https://doi.org/10.1177/2053019615605117, 2016.

Ruesch, A. and Gibbs, H. K.: New IPCC Tier-1 global biomass carbon map for the year 2000, Carbon Dioxide Information Analysis Center, Oak Ridge National Laboratory, 2008.

Savarino, J. and Legrand, M.: High northern latitude forest fires and vegetation emissions over the last millennium inferred from the chemistry of a central Greenland ice core, J. Geophys. Res., 103, 8267-8279, https://doi.org/10.1029/97JD03748, 1998.

Simoneit, B. R. T.: Biomass burning - A review of organic tracers for smoke from incomplete combustion, Appl. Geochem., 17, 129-162, https://doi.org/10.1016/S0883-2927(01)00061-0, 2002.

Simoneit, B. R. T. and Elias, V. O.: Organic tracers from biomass burning in atmospheric particulate matter over the ocean, Mar. Chem., 69, 301-312, https://doi.org/10.1016/S03044203(00)00008-6, 2000.

Simoneit, B. R. T., Schauer, J., Nolte, C., Oros, D., Elias, V., Fraser, M., Rogge, W., and Cass, G.: Levoglucosan, a tracer for cellulose in biomass burning and atmospheric particles, Atmos. Environ., 33, 173-182, https://doi.org/10.1016/S13522310(98)00145-9, 1999.
Simoneit, B. R. T., Kobayashi, M., Mochida, M., Kawamura, K., Lee, M., Lim, H.-J., Turpin, B. J., and Komazaki, Y.: Composition and major sources of organic compounds of aerosol particulate matter sampled during the ACE-Asia campaign, J. Geophys. Res., 109, D19S10, https://doi.org/10.1029/2004JD004598, 2004.

Slade, J. H. and Knopf, D. A.: Heterogeneous OH oxidation of biomass burning organic aerosol surrogate compounds: assessment of volatilisation products and the role of $\mathrm{OH}$ concentration on the reactive uptake kinetics, Phys. Chem. Chem. Phys., 15, 5898-915, https://doi.org/10.1039/C3CP44695F, 2013.

Soja, A. J., Tchebakova, N. M., French, N. H., Flannigan, M. D., Shugart, H. H., Stocks, B. J., Sukhinin, A. I., Parfenova, E., Chapin III, F. S., and Stackhouse Jr., P. W.: Climate-induced boreal forest change: Predictions versus current observations, Global Planet. Change, 56, 274-296, https://doi.org/10.1016/j.gloplacha.2006.07.028, 2007.

Stein, A., Draxler, R., Rolph, G., Stunder, B., Cohen, M., and Ngan, F.: NOAA's HYSPLIT atmospheric transport and dispersion modeling system, B. Am. Meteorol. Soc., 96, 2059-2077, https://doi.org/10.1175/BAMS-D-14-00110.1, 2015.

Stohl, A., Berg, T., Burkhart, J. F., Fjæraa, A. M., Forster, C., Herber, A., Hov, Ø., Lunder, C., McMillan, W. W., Oltmans, S., Shiobara, M., Simpson, D., Solberg, S., Stebel, K., Ström, J., Tørseth, K., Treffeisen, R., Virkkunen, K., and Yttri, K. E.: Arctic smoke - record high air pollution levels in the European Arctic due to agricultural fires in Eastern Europe in spring 2006, Atmos. Chem. Phys., 7, 511-534, https://doi.org/10.5194/acp-7511-2007, 2007.

Thompson, L. G., Davis, M. E., Mosley-Thompson, E., Sowers, T. A., Henderson, K. A., Zagorodnov, V. S., Lin, P.N., Mikhalenko, V. N., Campen, R. K., Bolzan, J. F., ColeDai, J., and Francou, B.: A 25,000-Year Tropical Climate History from Bolivian Ice Cores, Science, 282, 1858-1864, https://doi.org/10.1126/science.282.5395.1858, 1998.

Torrence, C. and Compo, G. P.: A practical guide to wavelet analysis, B. Am. Meteorol. Soc., $\quad 79, \quad 61-78, \quad$ https://doi.org/10.1175/15200477(1998)079<0061:APGTWA>2.0.CO;2, 1998.

Trouet, V., Esper, J., Graham, N. E., Baker, A., Scourse, J. D., and Frank, D. C.: Persistent Positive North Atlantic Oscillation Mode Dominated the Medieval Climate Anomaly, Science, 324, 78-80, https://doi.org/10.1126/science.1166349, 2009.

Trouet, V., Scourse, J., and Raible, C.: North Atlantic storminess and Atlantic Meridional Overturning Circulation during the last Millennium: Reconciling contradictory proxy records of NAO variability, Global Planet. Change, 84-85, 48-55, https://doi.org/10.1016/j.gloplacha.2011.10.003, 2012.

Wang, Y., Cheng, H., Edwards, R. L., He, Y., Kong, X., An, Z., Wu, J., Kelly, M. J., Dykoski, C. A., and Li, X.: The Holocene Asian Monsoon: Links to Solar Changes and North Atlantic Climate, Science, 308, 854-857, https://doi.org/10.1126/science.1106296, 2005.

Wang, Z., Chappellaz, J., Park, K., and Mak, J.: Large variations in Southern Hemisphere biomass burning during the last 650 years, Science, 330, 1663-1666, https://doi.org/10.1126/science.1197257, 2010.

Wendl, I. A., Eichler, A., Isaksson, E., Martma, T., and Schwikowski, M.: 800-year ice-core record of nitrogen de- 
position in Svalbard linked to ocean productivity and biogenic emissions, Atmos. Chem. Phys., 15, 7287-7300, https://doi.org/10.5194/acp-15-7287-2015, 2015.

Wessel, P. and Smith, W. H.: A global, self-consistent, hierarchical, high-resolution shoreline database, J. Geophys. Res., 101, 87418743, https://doi.org/10.1029/96JB00104, 1996.

Zagorodnow, V. S.: Recent Soviet activities on ice core drilling and core investigations in Arctic region, Bulletin of Glacier Research, 6, 81-84, 1988.

Zangrando, R., Barbaro, E., Zennaro, P., Rossi, S., Kehrwald, N. M., Gabrieli, J., Barbante, C., and Gambaro, A.: Molecular markers of biomass burning in Arctic aerosols, Environ. Sci. Technol., 47, 8565-8574, https://doi.org/10.1021/es400125r, 2013.
Zangrando, R., Barbaro, E., Vecchiato, M., Kehrwald, N. M., Barbante, C., and Gambaro, A.: Levoglucosan and phenols in Antarctic marine, coastal and plateau aerosols, Sci. Total Environ., 544, 606-616, https://doi.org/10.1016/j.scitotenv.2015.11.166, 2016.

Zennaro, P., Kehrwald, N., McConnell, J. R., Schüpbach, S., Maselli, O. J., Marlon, J., Vallelonga, P., Leuenberger, D., Zangrando, R., Spolaor, A., Borrotti, M., Barbaro, E., Gambaro, A., and Barbante, C.: Fire in ice: two millennia of boreal forest fire history from the Greenland NEEM ice core, Clim. Past, 10, 1905-1924, https://doi.org/10.5194/cp-10-1905-2014, 2014. 